\title{
Pothos (Epipremnum aureum) Diseases: Identification and Control in Commercial Greenhouse Production ${ }^{1}$
}

\author{
David J. Norman and G. Shad Ali
}

The tropical ornamental vine Epipremnum aureum (plant family Araceae), commonly known as pothos, has been grown commercially in the United States for almost 100 years. Pothos consistently ranks among the top wholesale production foliage plants in Florida (Figure 1). It is usually produced in hanging baskets for the patio, as climbing totem poles for commercial offices, or in small pots for dish gardens. Pothos is commonly used as an interiorscape plant due to its ease of growing, hardiness, and visual appeal.

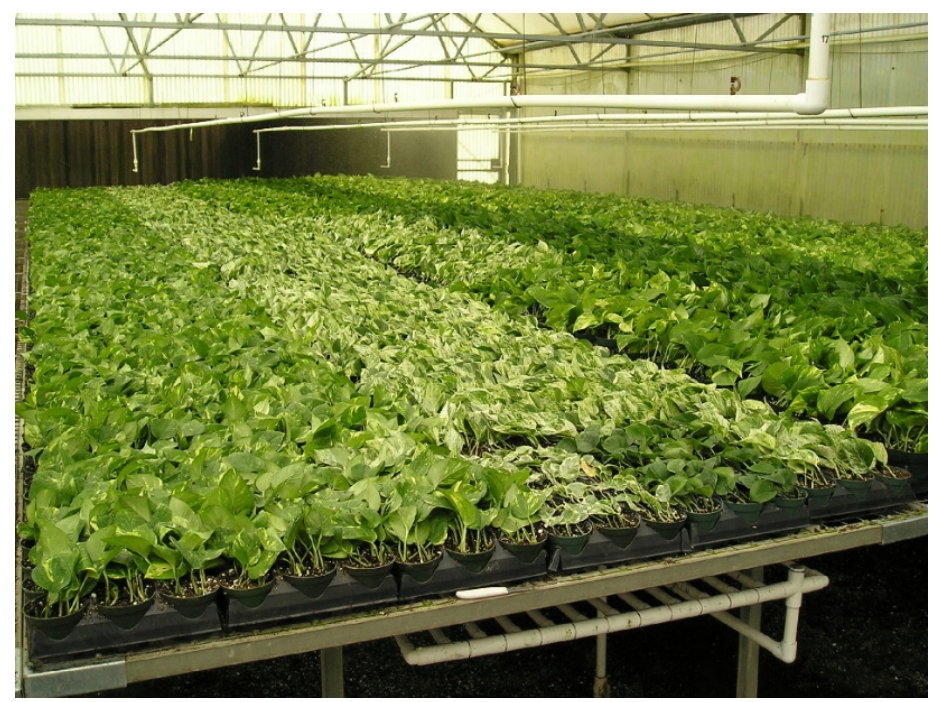

Figure 1. Commercial production of pothos.

Credits: R. J. Henny, UF/IFAS
Several varieties of pothos are grown commercially. 'Golden Pothos', with intense yellow variegation on leaves against a deep green background, is perhaps the most recognizable. 'Marble Queen' is a green and white variegated leaf variety introduced during the 1970s. 'Hawaiian' pothos has larger-than-average leaves. Pothos 'Pearls and Jade' and 'Njoy' have elongated, flat leaves with showy cream and grey-green speckles. Solid green 'Jade' has traditional heart-shaped leaves, 'Green Genie' is deep emerald with round, small, thick leaves, and 'Neon' is chartreuse in color.

Much of the propagation material for pothos is grown in Central America or in the Caribbean countries. Vines for stock may be grown under a number of different environments, from greenhouse facilities to ground beds or near jungle environments. Single-node cuttings are commercially harvested and sent to the US for rooting and growing. These cuttings frequently arrive infected with diseases.

This publication addresses identification and treatment of common bacterial and fungal diseases encountered during commercial greenhouse production of pothos. Crop damage due to poor cultural practices is frequently mistaken for disease. The first step in preventing any disease outbreak in a production facility is to inspect the unrooted cuttings and liner materials for the presence of disease when they are received. Discard any materials that appear to harbor disease. Growers should purchase liner materials from licensed nurseries with reliable, clean sources. Using clean

1. This document is PP340, one of a series of the Plant Pathology Department, UF/IFAS Extension. Original publication date July 2018. Visit the EDIS website at http://edis.ifas.ufl.edu.

2. David J. Norman, professor; and G. Shad Ali, assistant professor; UF/IFAS Extension, Plant Pathology Department, UF/IFAS Mid-Florida Research and Education Center, Apopka, FL 32703.

The Institute of Food and Agricultural Sciences (IFAS) is an Equal Opportunity Institution authorized to provide research, educational information and other services only to individuals and institutions that function with non-discrimination with respect to race, creed, color, religion, age, disability, sex, sexual orientation, marital status, national origin, political opinions or affiliations. For more information on obtaining other UF/IFAS Extension publications, contact your county's UF/IFAS Extension office. 
stock and maintaining good cultural conditions during production are key to any disease-management strategy (McConnell, Chen, Henny and Everitt 2015).

\section{Phytophthora}

The most common disease infecting pothos is Phytophthora root rot. This disease is frequently introduced via imported propagative cuttings (Futch and Graham 2015).

\section{Symptoms}

Infection usually starts in the roots, eventually spreading to leaves and throughout the whole plant. Phytophthora root rot causes pothos leaves to turn dark brown to black (Figure 2). The veins in the leaves and stems do not blacken with infection.

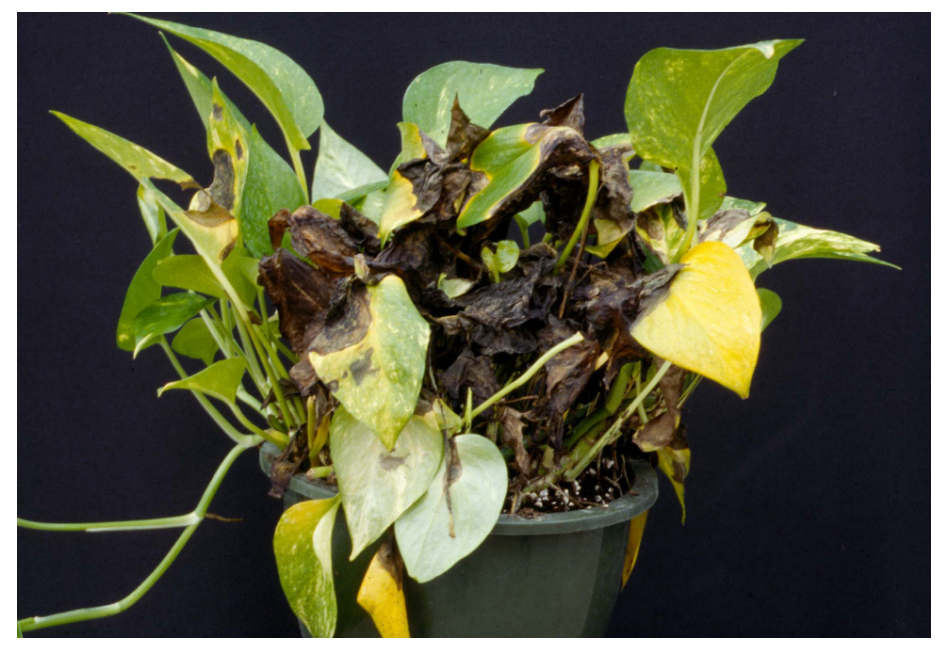

Figure 2. Phytophthora root rot of pothos. Note the dark brown leaves. Credits: Dr. David Norman, UF/IFAS

\section{Causal Agent}

A watermold, Phytophthora nicotianae, causes this disease. Under irrigation, Phytophthora produces zoospores. Zoospores have the ability to swim and spread the infection. Zoospores can remain active for hours to days depending on greenhouse temperature and moisture. The disease can easily be spread through contaminated water and water splashed from infected plants during overhead irrigation.

\section{Control and Treatment}

In commercial greenhouse production, exclusion is the best method of controlling this disease. Pothos plants expressing symptoms should be discarded. Because Phytophthora zoospores are readily transported via water, reducing irrigation volumes will help control disease spread. Remaining plants should be treated with an appropriate fungicide, such as aluminum tris/Fosetyl-al (Aliette ${ }^{\circledR}$ WDG), dimethomorph (Stature $\left.{ }^{\circledR}\right)$, dimethomorph + ametoctradin $\left(\right.$ Orvego $\left.^{\mathrm{TM}}\right)$, fluopicolide (Adorn ${ }^{\mathrm{TM}}$ ), and phosphorous acid (Alude ${ }^{\mathrm{TM}}$,
K-Phite ${ }^{\circledR}$, Vital ${ }^{\circledR}$ ), to effectively control Phytophthora. For more information on fungicide selection, please visit the Homeowner's Guide to Fungicides for Lawn and Landscape Disease Management or the Fungicide Resistance Action Committee's (FRAC) Classification Scheme of Fungicides According to Mode of Action.

\section{Common Physiological Disorders of Pothos that Resemble Phytophthora}

Ethylene damage and certain fungicides may cause foliage conditions that closely resemble disease but are not caused by fungal, bacterial, or viral organisms. For accurate diagnosis, close examination of plant samples for the presence or absence of the pathogen is necessary.

\section{ETHYLENE DAMAGE}

Ethylene damage is most often seen in the fall and winter.

\section{Symptoms}

Ethylene causes pothos foliage to turn yellow, then tan to light brown (Figure 3). Plants may appear wilted even though soil moisture is adequate.

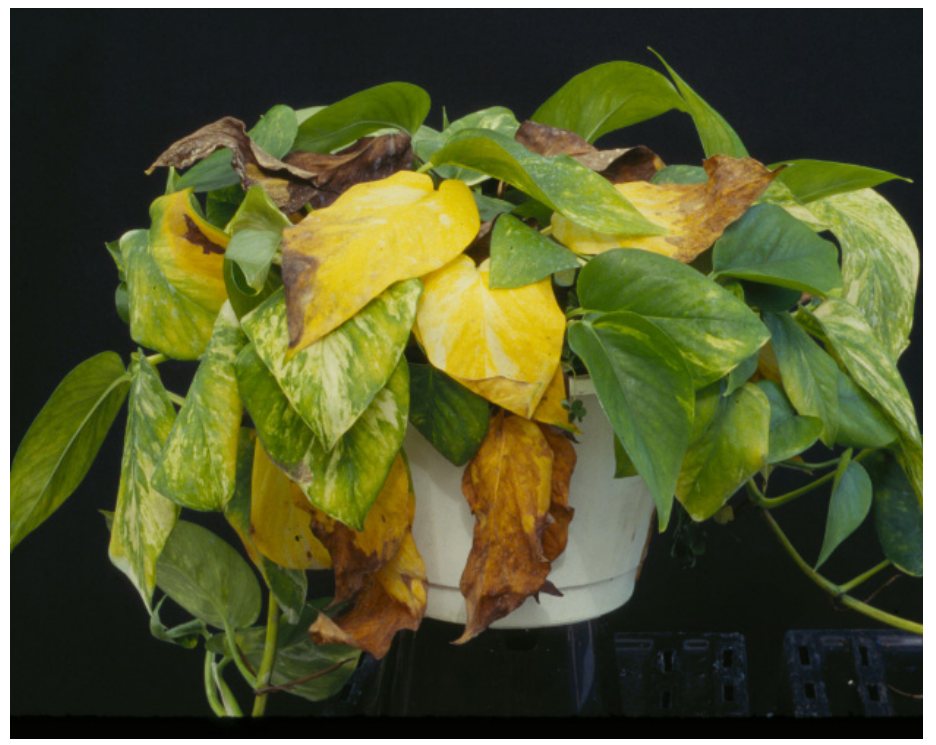

Figure 3. Ethylene damage of pothos. Note the light brown leaves. Credits: Dr. David Norman, UF/IFAS

\section{Causal Agent}

Ethylene is a naturally occurring gas released from decomposing plant matter and some ripening fruit. It may also be generated by malfunctioning greenhouse heaters in the winter and will accumulate under conditions of poor ventilation. Ethylene has been known to accumulate in trucks during shipping. Ethylene acts to induce blooming of certain crops, and, if allowed to escape, it could affect nearby plants in a multi-crop production facility. 


\section{Control and Treatment}

Inspect greenhouse heaters for proper operation prior to winter usage. Ensure adequate ventilation is present in the greenhouse. Apply ethylene treatments carefully in a multi-crop system. Avoid mixed loads of floral, foliage, and vegetable products during shipping if possible.

\section{FUNGICIDE OR CHEMICAL APPLICATION DAMAGE}

Pothos foliage is sensitive to certain chemical sprays.

\section{Symptoms}

White bleaching and tip burn of pothos leaves are caused by applications of fungicides containing mefenoxam (Figure 4).

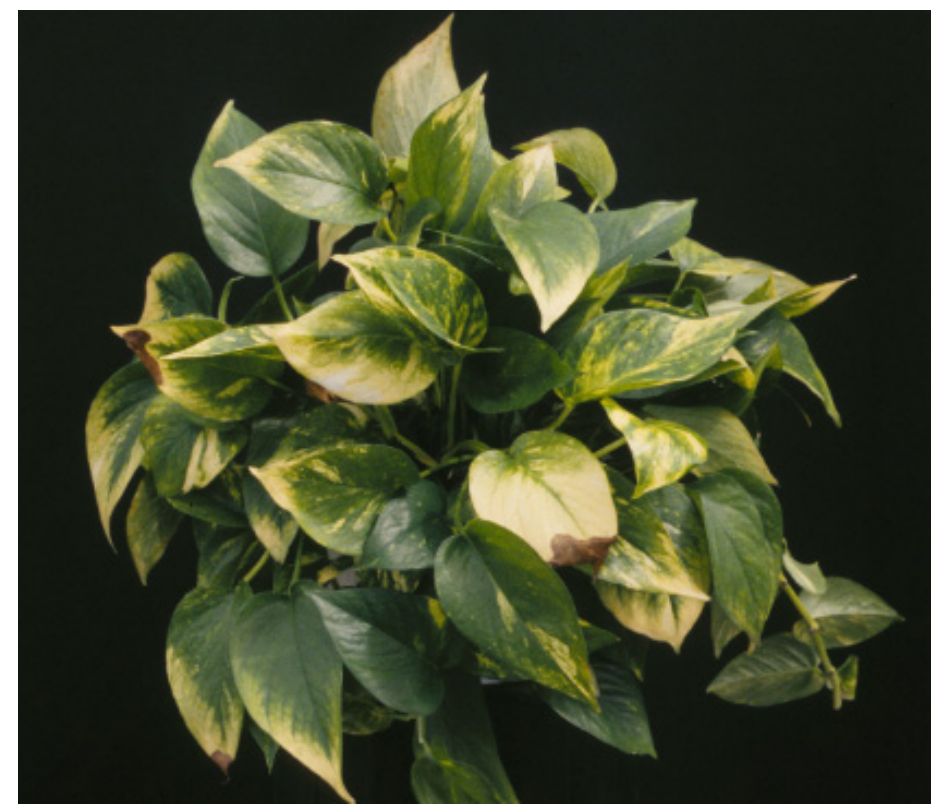

Figure 4. Fungicide damage (mefenoxam) of pothos. Note marginal bleaching of leaves.

Credits: Mary Brennan, UF/IFAS

\section{Causal Agent}

Fungicides containing mefenoxam are known to cause leaf burn and bleaching in pothos. Application of fungicides and chemicals during the hottest times of day may also cause symptoms.

\section{Control and Treatment}

Always test new chemicals on a small sample of the crop before applying any spray to the entire greenhouse. Apply spray during cooler times of the day (in early morning or in the evening). Avoid chemicals known to cause damage.

\section{Bacterial Wilt Disease}

Bacterial wilt disease is most commonly observed in commercial production of pothos at the single-node rooting stage. Infected cuttings fail to root and losses in propagation beds can approach 100\% (Pernezny, Elliott, Palmateer and Havranek 2017).

\section{SYMPTOMS}

Bacterial wilt causes pothos leaves to wilt. Veins in the leaves and stems turn black (Figure 5). If infected stems are cut and placed in water, one can observe millions of bacteria being released. It is common to observe bacterial ooze on recently cut stems (Figure 6).

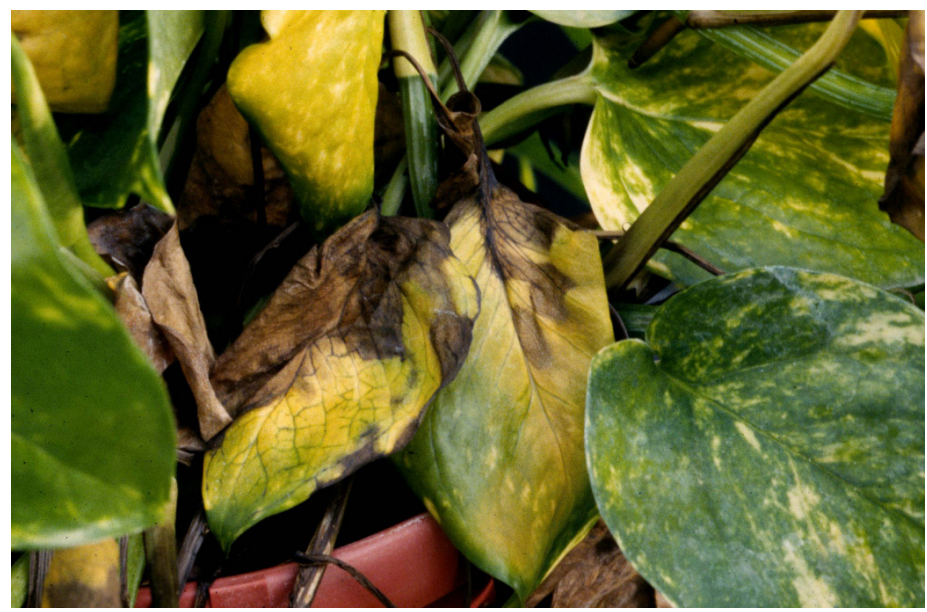

Figure 5. Bacterial wilt of pothos. Note the discolored veins. Credits: Dr. David Norman, UF/IFAS

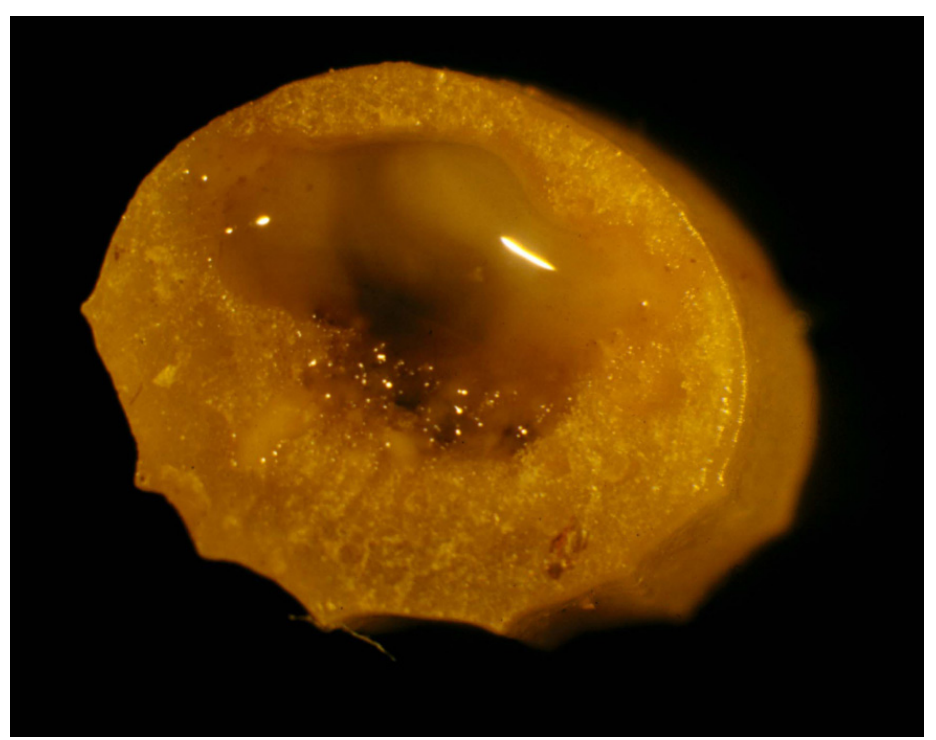

Figure 6. Bacterial ooze on recently cut pothos stem. Credits: Dr. David Norman, UF/IFAS

\section{CAUSAL AGENT}

The bacteria Ralstonia solanacearum causes this disease. The bacteria have the ability to swim, but the primary movement is passive, with bacteria being transported in irrigation water. The bacteria infect through root hairs and wounds during propagation and handling. 


\section{CONTROL AND TREATMENT}

Symptoms are especially severe during warm periods of the year.

Bacterial multiplication is rapid, and an aggressive sanitation program will be needed. If an outbreak occurs, plants, soil, and pots should be bagged and removed from the nursery. Benches and tools should be disinfected before any replanting is done. There are no effective bactericides that can be used in a nursery setting.

\section{Rhizoctonia Root Rot and Aerial Blight}

Pothos leaves are very susceptible to Rhizoctonia blight throughout production from Rhizoctonia solani spores in the soil. Rhizoctonia root rot can cause significant damage to pothos cuttings during the rooting stage (Harmon and Bledsoe 2015).

\section{SYMPTOMS}

Rhizoctonia causes irregular, dark, necrotic spots on pothos leaves (Figure 7). Leaves mat together and strands of the fungus may be visible. If Rhizoctonia infects roots during propagation, cuttings will wilt, turn dark brown, and die.

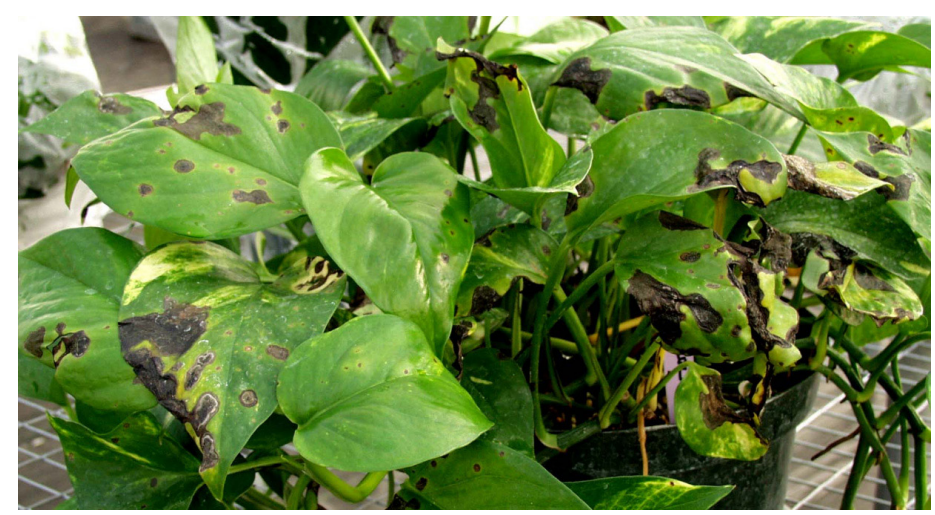

Figure 7. Rhizoctonia blight on pothos leaves.

Credits: Dr. David Norman, UF/IFAS

\section{CAUSAL AGENT}

A fungus, Rhizoctonia solani, which usually gains access to production facilities via contaminated potting soil mixes.

\section{CONTROL AND TREATMENT}

Rhizoctonia should not be a problem in pothos greenhouse production if disease-free cuttings are used and if soil mixes do not contain native (nonsterilized), local soils. Pothos plants in greenhouse production should be kept on raised benches elevated off the soil surface. Infected plants should be identified, bagged, and discarded. If the disease cannot be managed through sanitation, applications of triflumizole (Terragard ${ }^{\circledR}$ ) or thiophanate-methyl (Clearys $3336^{\mathrm{TM}}$, OHP $6672^{\mathrm{TM}}$ ) may be effective. For more information on fungicide selection, please visit the Professional Disease Management Guide for Ornamental Plants.

\section{Southern Blight}

Southern blight is common in warm southern climates. This pathogen is rarely found any farther north than Georgia; however, once transported in plant material, it can thrive in greenhouses anywhere in the United States (Xie and Vallad 2016).

\section{SYMPTOMS}

Visible strands of fungus are usually the first indication that a grower has southern blight. White, feathery strands of fungal mycelia grow along the soil surface and up plant stems. This fungus produces oxalic acid, pectolytic enzymes, and cellulolytic enzymes to dissolve pothos cell walls. One of the key features of this fungus is the production of sclerotia (Figure 8). Sclerotia are found wherever white fungal masses have grown, whether on soil or plant material. These sclerotia are small, spherical, compact masses of hyphae, which, when newly formed, are white, later turning yellow, then orange, and finally brown. Sclerotia are the primary mechanism by which this fungus survives unfavorable environmental conditions such as desiccation, heat, and penetration of fungicides.

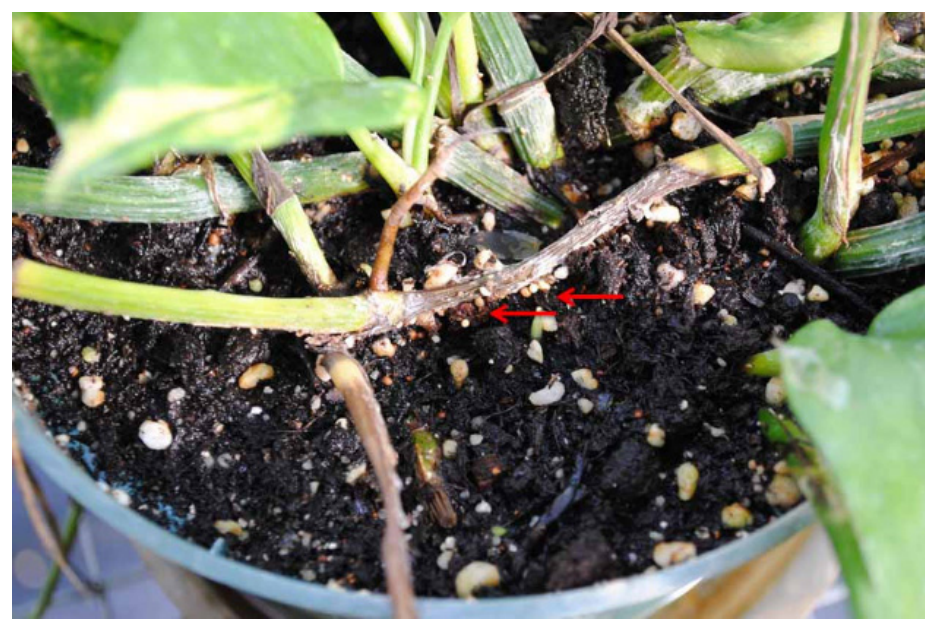

Figure 8. Southern blight of photos. Note the stem rot and white to orange scolerotia on stem.

Credits: Dr. David Norman, UF/IFAS

\section{CAUSAL AGENT}

This disease is caused by the fungus Sclerotium rolfsii. Growth of this fungus is especially rapid when weather conditions are hot and soils remain wet.

\section{CONTROL AND TREATMENT}

Avoid storing potting mixes directly on the ground. Sclerotium can colonize wood chips and soil without having a host plant present. Southern blight usually gains access to 
greenhouse facilities via contaminated soil. Discard infected plants and do not reuse pots. Sclerotia frequently cling to the sides of pots and will infect the next crop planted. Remaining pothos may be treated with a fungicide drench containing pentachloronitrobenze (PCNB) or flutolanil. For more information on fungicide selection, please visit the Homeowner's Guide to Fungicides for Lawn and Landscape Disease Management or the Fungicide Resistance Action Committee's (FRAC) Classification Scheme of Fungicides According to Mode of Action.

\section{Manganese Toxicity}

Excess amounts of the element manganese can cause pothos foliage conditions that resemble disease but are not caused by fungal, bacterial, or viral organisms. Manganese toxicity is more common in older pothos plants used to supply cutting materials.

\section{SYMPTOMS}

Older pothos leaves show yellow flecking or spotting (Figure 9). Veins may darken. Leaves may drop prematurely. This condition is usually seen in stock plants.

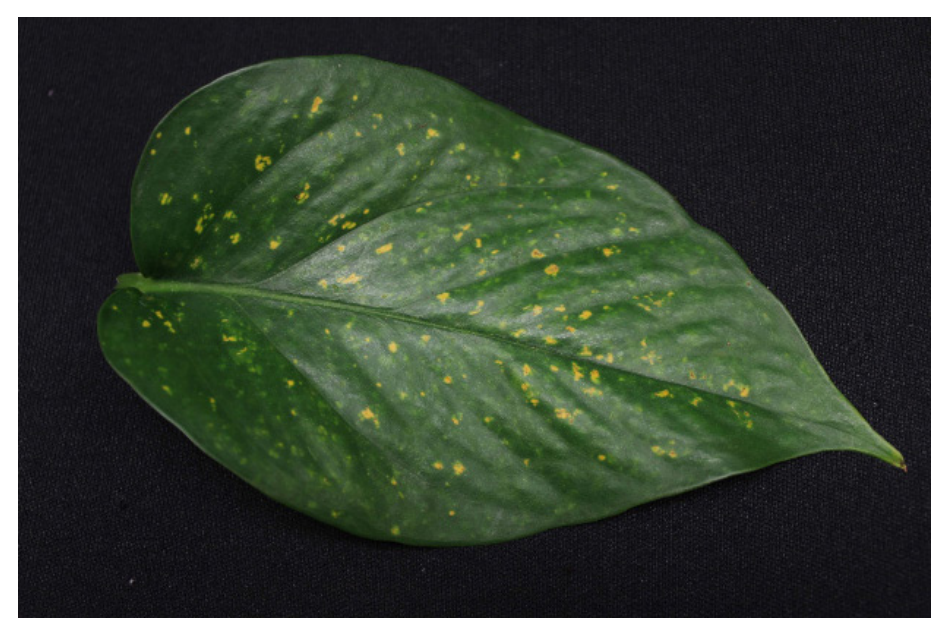

Figure 9. Manganese toxicity of pothos. Note the yellow flecking. Credits: Mary Brennan and Dr. G. Shad Ali, UF/IFAS

\section{CAUSAL AGENT}

Too much manganese is absorbed by the plant. This may be caused by excess micronutrient fertilization, acidification of the potting soil to 5.0 or below, or accumulation of manganese from fungicide applications.

\section{CONTROL AND TREATMENT}

Discontinue fertilization with the element manganese in fertilizer formulations. Do not apply trace-element mixes. Apply lime to raise soil pH to a range between 6.0 to 6.5. Discontinue use of fungicides containing manganese such as maneb or mancozeb. Establish fresh plantings for stock.

\section{References}

Futch, S. H. and J. H. Graham. 2015. Field Diagnosis and Management of Phytophthora Diseases. HS-1015. Gainesville: University of Florida Institute of Food and Agricultural Sciences. http://edis.ifas.ufl.edu/hs261

Harmon, P. F. and S. D. Bledsoe. 2015. Professional Disease Management Guide for Ornamental Plants. PP202. Gainesville: University of Florida Institute of Food and Agricultural Sciences. http://edis.ifas.ufl.edu/pp123

McConnell, D. B., J. J. Chen, R. J. Henny, and K. C. Everitt. 2017. Cultural Guidelines for Commercial Production of Interiorscape Epipremnum. ENH894. Gainesville: University of Florida Institute of Food and Agricultural Sciences. http://edis.ifas.ufl.edu/ep151

Pernezny, K., M. Elliot, A. Palmateer, and N. Havranek. 2017. Guidelines for Identification and Management of Plant Disease Problems: Part II. Diagnosing Plant Disease Caused by Fungi, Bacteria and Viruses. PP249. Gainesville: University of Florida Institute of Food and Agricultural Sciences. http://edis.ifas.ufl.edu/mg442

Xie, C. and G. Vallad. 2016. Integrated Management of Southern Blight in Vegetable Production. PP272. Gainesville: University of Florida Institute of Food and Agricultural Sciences. http://edis.ifas.ufl.edu/pp272 